\title{
Quantitative Analysis of Human Hair for Selenium(IV), Selenium(VI) and Total Selenium by Hydride-Generation Atomic Absorption Spectrometry
}

\author{
Xiaonan Dong, Yuzuru NakaguchI and Keizo HiRaki ${ }^{\dagger}$ \\ Department of Chemistry, Faculty of Science and Technology, Kinki University, \\ Kowakae, Higashi-Osaka 577, Japan
}

\begin{abstract}
Optimized procedures were established for the determination of total $\mathrm{Se}$, organic $\mathrm{Se}, \mathrm{Se}$ (IV), and $\mathrm{Se}$ (VI) in human hair by means of hydride-generation atomic absorption spectrometry (HGAAS), respectively. Using this method, the total Se content in a hair sample was determined through pretreating the sample with nitric acid-perchloric acid, and then reducing $\mathrm{Se}$ (VI) to $\mathrm{Se}$ (IV) with $6.0 \mathrm{~mol} \mathrm{dm}^{-3}$ hydrochloric acid; however, for individual $\mathrm{Se}(\mathrm{IV}), \mathrm{Se}$ (VI) or soluble $\mathrm{Se}$, after the hair sample was immersed into water and disrupted ultrasonically for $8 \mathrm{~h}$ at room temperature, 2,3diaminonaphthalene (DAN) reagent was added to extract Se(IV). The sum of Se(IV) and Se(VI) was determined by extracting $\mathrm{Se}(\mathrm{IV})$ after reducing all of the $\mathrm{Se}$ (VI) into $\mathrm{Se}$ (IV) with the addition of potassium bromide. Se(VI) was obtained by subtracting $\mathrm{Se}$ (IV) from the sum of $\mathrm{Se}$ (IV) and $\mathrm{Se}$ (VI). The content of organic Se in the hair sample was

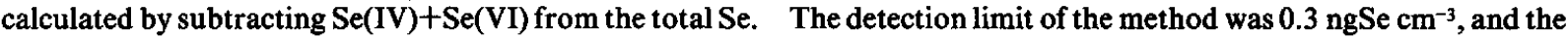
average precision (relative standard deviation) was less than $5 \%(n=6)$.
\end{abstract}

Keywords Hydride generation atomic absorption spectrometry, ultrasonic leaching, human hair sample, selenium(IV), selenium(VI), soluble selenium

Selenium is an interesting trace element in human tissues because of its dual roles as both an essential nutrient at a low concentration level and a toxic substance at a higher concentration level. The toxicity of Se depends greatly on its chemical form. ${ }^{1-3}$ Thus, much attention has recently been paid to the levels of Se in human tissues. It has been found that its quantity in hair is closely correlated to that inside; the body.4,5 Obviously, determining its content in hair could provide a simple way for monitoring the change of the Se status in vivo. Since $\mathrm{Se}$ is found at trace levels (usually $\mathrm{ng} \mathrm{g}^{-1}$ or sub $n g \mathrm{~g}^{-1}$ ), and two forms (inorganic and organic) of the element exist in hair, a sensitive, stable and simple analytical method is required. In previous work we determined the respective concentrations of various Se species in natural water samples by fluorometry. However, this method has several problems during the analytical procedures: 1) the 2,3-diaminonaphthalene (DAN) reagent requires purification; 2) the sample solution requires many repeated extractions; and 3 ) it takes a long time and a complex operation is required. We thus attempted to use hydride-generation atomic absorption spectrometry (HGAAS) ${ }^{6-13}$ combined with an ultrasonic leaching method for Se, which has been confirmed to be not only convenient, but also effective for keeping them intact; to determine $\mathrm{Se}$ (IV) and $\mathrm{Se}$ (VI)

† To whom correspondence should be addressed. in human hair samples, on the other hand, wet digestion $\left(\mathrm{HNO}_{3}-\mathrm{HClO}_{4}\right)$ was employed to measure the total amount of Se. Moreover, optimized instrumental conditions for the HGAAS system in analyzing human hair for Se have been established. The results from a number of determinations on hair samples have shown that these instrumental conditions and sample pretreatment procedures could provide a satisfactory approach for a quantitative analysis for Se species in living systems.

\section{Experimental}

\section{Apparatus}

A Hitachi (Model 180-70) atomic absorption spectrometer equipped with a commercial hydride-generation system (HFS-2) and a peristaltic pump was used. A Se hollow cathode lamp (Hitachi) served as a light source of $196.0 \mathrm{~nm}$ wavelength (with a slit of $1.3 \mathrm{~nm}$, and working current of $12.5 \mathrm{~mA})$. The temperature of the quartz atomizer tube $(120 \mathrm{~mm}$ in length and $13 \mathrm{~mm}$ in inner diameter) was set at $900^{\circ} \mathrm{C}$. The absorbance signals in the peak-height mode were recorded on a Rikadenki Model R-01 recorder. An ultrasonic clean bath (Kaijo Denki Co., Ltd. Japan, freq. $38 \mathrm{kHz}$ ) was used for leaching the element from hair samples. 


\section{Reagents}

All of the reagents used were of highly pure grade; doubly distilled water was used throughout. A sodium tetrahydroborate $\left(\mathrm{NaBH}_{4}\right)$ solution $(1.5 \% \mathrm{w} / \mathrm{v})$ in $0.8 \%$ sodium hydroxide $(\mathrm{NaOH})$ was freshly prepared before the experiments. A $1000 \mathrm{mg} \mathrm{dm}^{-3}$ stock solution of Se(IV) was prepared by dissolving $0.144 \mathrm{~g}$ of Se dioxide in $100 \mathrm{~cm}^{3}$ of $1.0 \mathrm{~mol} \mathrm{dm} \mathrm{dm}^{-3}$ hydrochloric acid $(\mathrm{HCl})$. The standard solutions for a calibration were obtained by diluting the stock solution before use.

\section{Sample pretreatment}

All human hair used in this study (without permed and dyed) was obtained from a barbershop, and washed with $0.3 \%$ polyoxyethylene lauryl alcohol ether for $20 \mathrm{~min}$. After being rinsed with doubly distilled water and dried at $80^{\circ} \mathrm{C}$, the sample was powdered under liquid nitrogen, and then homogenized in the presence of argon in a closed acid-washed glass beaker, and finally stored in a desiccator prior to analyses..$^{5,14,15}$

\section{Determination of total Se}

First, $0.2 \mathrm{~g}$ of the pretreated hair sample was placed in a $100 \mathrm{~cm}^{3}$ beaker with $5 \mathrm{~cm}^{3}$ of concentrated nitric acid $\left(\mathrm{HNO}_{3}\right)$ and covered with a glass dish over night; after the beaker was heated at $100^{\circ} \mathrm{C}$ for $4 \mathrm{~h}, 2.0 \mathrm{~cm}^{3}$ of perchloric acid $\left(\mathrm{HClO}_{4}\right)$ was added to the sample solution; then, after being subjected to reflux for an additional $3 \mathrm{~h}$, the acid was allowed to evaporate by removing the cover until white fumes of $\mathrm{HClO}_{4}$ appeared; this procedure was then repeated once again until the solution became colorless. The solution was carefully concentrated to ca. $0.3 \mathrm{~cm}^{3}$. At no time was the residue allowed to dry or char, since Se losses could occur. After cooling, $2.0 \mathrm{~cm}^{3}$ of $6.0 \mathrm{~mol} \mathrm{dm}^{-3} \mathrm{HCl}$ was added to the residue, which was heated at $100^{\circ} \mathrm{C}$ for $10 \mathrm{~min}$ to reduce $\mathrm{Se}$ (VI) into $\mathrm{Se}(\mathrm{IV}) .^{16-18}$ Finally, the solution was transferred into a $20 \mathrm{~cm}^{3}$ volumetric flask for a following determination.

\section{Determination of $\operatorname{Se}(\mathrm{IV})$}

About $30 \mathrm{~g}$ of a pretreated hair sample was put into a $200 \mathrm{~cm}^{3}$ glass flask with $100 \mathrm{~cm}^{3}$ of doubly distilled water; then, ultrasonic leaching was conducted for $8 \mathrm{~h}$ in a ultrasonic bath. ${ }^{10}$ After being filtered through a 0.45 $\mu \mathrm{m}$ membrane filter, the leached solution which was acidified to $\mathrm{pH}=1$ with dilute $\mathrm{HCl}$; then, after the addition of $5 \mathrm{~cm}^{3}$ of $0.1 \mathrm{~mol} \mathrm{dm}{ }^{-3}$ EDTA-NaF and $20 \mathrm{~cm}^{3}$ of $0.1 \%$ DAN reagent, the solution was warmed at $50^{\circ} \mathrm{C}$ for $30 \mathrm{~min}$ in a water bath. After being cooled to room temperature, the solution was transferred to a seperatory funnel containing $15 \mathrm{~cm}^{3}$ of cyclohexane, and shaken for $10 \mathrm{~min}$. The aqueous part was removed and $10 \mathrm{~cm}^{3}$ of concentrated $\mathrm{HNO}_{3}$ was added into the organic part. Shaking was performed for $5 \mathrm{~min}$ to make the Se extracted back to the aqueous layer, which was then concentrated on a hot plate to $\mathrm{ca} .0 .3 \mathrm{~cm}^{3}$ and transferred to a $10 \mathrm{~cm}^{3}$ volumetric flask ${ }^{17}$ for the HGAAS determination.
Table 1 Optimized instrumental conditions for determination of $\mathrm{Se}(\mathrm{IV})$

\begin{tabular}{ll} 
Wavelength & $196.0 \mathrm{~nm}$ \\
Lamp current & $12.5 \mathrm{~mA}$ \\
Slit & $1.3 \mathrm{~nm}$ \\
Flame temperature & $900^{\circ} \mathrm{C}$ \\
$\mathrm{NaBH}_{4}$ concentration & $1.5 \%(\mathrm{w} / \mathrm{v})$ \\
$\mathrm{NaBH}_{4}$ flow rate & $6.5 \mathrm{~cm}^{3} \mathrm{~min}^{-1}$ \\
$\mathrm{HCl}$ concentration & $3.0 \mathrm{~mol} \mathrm{dm}^{-3}$ \\
$\mathrm{HCl}$ flow rate & $5.5 \mathrm{~cm}^{3} \mathrm{~min}^{-1}$ \\
Flow rate of argon gas & $500 \mathrm{~cm}^{3} \mathrm{~min}^{-1}$ \\
Sampling time & $0.2 \mathrm{~min}^{-1}$ \\
Sample flow rate & $7.5 \mathrm{~cm}^{3} \mathrm{~min}^{-1}$ \\
\hline
\end{tabular}

\section{Determination of $\mathrm{Se}(\mathrm{IV})+\mathrm{Se}(\mathrm{VI})$}

As described, to the sample solution, which was ultrasonically leached and filtered, $2.0 \mathrm{~g}$ of $\mathrm{KBr}$ was added to reduce $\mathrm{Se}(\mathrm{VI})$ to $\mathrm{Se}(\mathrm{IV})^{16-18}$, which was then followed by an identical procedure to that used for treating Se(IV) mentioned above; that is, the sum concentration of $\mathrm{Se}(\mathrm{IV})$ and $\mathrm{Se}(\mathrm{VI})$ was determined. The quantity of $\mathrm{Se}$ (VI) was then obtained by subtracting the concentration of Se(IV) from the sum concentration.

\section{Analysis of dissolved organic Se}

First, $10 \mathrm{~g}$ of a prepared hair sample with $30 \mathrm{~cm}^{3}$ was ultrasonically leached in a $100 \mathrm{~cm}^{3}$ for $8 \mathrm{~h}$. After being filtered, $10 \mathrm{~cm}^{3}$ of concentrated $\mathrm{HNO}_{3}$ was added and heated to almost dry; then, another $10 \mathrm{~cm}^{3}$ of $\mathrm{HNO}_{3}$ and $2 \mathrm{~cm}^{3}$ of $\mathrm{HClO}_{4}$ were added. When the solution was nearly dry, $3 \mathrm{~cm}^{3}$ of $6 \mathrm{~mol} \mathrm{dm}^{-3} \mathrm{HCl}$ was added for reducing $\mathrm{Se}$, after which the total dissolved $\mathrm{Se}$ was determined as described above. The level of dissolved organic Se in the sample was calculated from the total dissolved Se, substracting the sum of $\mathrm{Se}(\mathrm{IV})$ and $\mathrm{Se}$ (VI).

\section{Results and Discussion}

\section{Optimization of the experimental parameters for the $\mathrm{HG}$ - $A A S$ system}

It has been reported that, generally, three factors can affect the quantitative analysis for selenium by using the HGAAS system. These include: (1) the concentration of the $\mathrm{NaBH}_{4}$ and $\mathrm{HCl}$ solution, (2) the atomization temperature and (3) the flow rate of the carrier gas. ${ }^{19}$ Thus, the optimization of these three factors was carried out. The results are summarized in Table 1 . The detection limit $(3 \sigma)$ of this method was $0.3 \mathrm{ngSe} \mathrm{cm}^{-3}$, when the sample volume of $10 \mathrm{~cm}^{3}$ was applied.

\section{Leaching of Se(IV), Se(VI) and organic Se}

According to the method and conditions mentioned above, the dissolved Se species were determined for 2, 4, 6,8 and $10 \mathrm{~h}$ of the leaching duration, respectively. From Fig. 1 it can be seen that the leaching duration would facilitate the dissolution of the inorganic Se from 


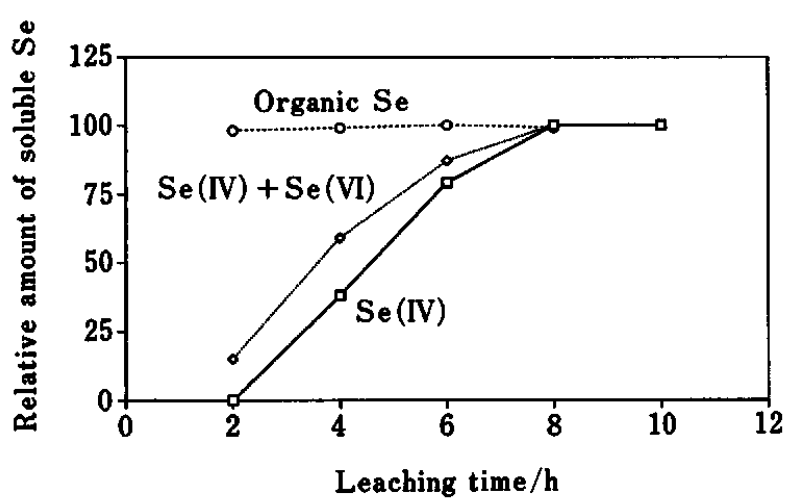

Fig. 1 Effect of the leaching time on the Se species from hair samples.

Table 2 Effect of diverse ions on the determination of $\mathrm{Se}(\mathrm{IV})$ at $5 \mathrm{ng} \mathrm{cm}^{-3}$ level

\begin{tabular}{|c|c|c|}
\hline Ion & Concentration $/ \mathrm{ng} \mathrm{cm}^{-3}$ & Recovery of Se(IV), \% \\
\hline $\mathrm{Al}(\mathrm{III})$ & 500 & 100 \\
\hline As(III) & 100 & 97 \\
\hline $\mathrm{Co}(\mathrm{II})$ & 100 & 100 \\
\hline $\mathrm{Cr}$ (III) & 200 & 101 \\
\hline $\mathrm{Cu}$ (II) & 500 & 98 \\
\hline $\mathrm{Fe}$ (III) & 500 & 97 \\
\hline $\mathrm{Fe}(\mathrm{II})$ & 300 & 99 \\
\hline $\operatorname{Mn}(I I)$ & 200 & 100 \\
\hline Ni(II) & 200 & 100 \\
\hline Pd(II) & 300 & 99 \\
\hline $\mathrm{Sb}(\mathrm{III})$ & 100 & 100 \\
\hline $\operatorname{Sn}(\mathrm{II})$ & 300 & 98 \\
\hline $\mathrm{Zn}(\mathrm{II})$ & 300 & 100 \\
\hline $\mathrm{NO}_{3}^{-}$ & 40000 & 99 \\
\hline $\mathrm{PO}_{4}{ }^{3-}$ & 30000 & 100 \\
\hline $\mathrm{SO}_{4}{ }^{2-}$ & 50000 & 100 \\
\hline
\end{tabular}

the hair sample. However, when the leaching time is over $8 \mathrm{~h}$, such dissolution reaches to a plateau, indicating that 7 to $8 \mathrm{~h}$ would be proper for the leaching of Se. On the other hand, the leaching rate of Se(IV) differs from that of $\mathrm{Se}(\mathrm{VI})$.

\section{Evaluation of potential interference}

It is well known that copper(II), nickel(II), iron(III), and tin(II) are potential interferents for the HGAAS of Se. ${ }^{10,20-22}$ To study the effect of diverse ions on the determination of Se with this procedure, the desired amount of each ion was added into a solution containing $5 \mathrm{ng} \mathrm{cm}^{-3} \mathrm{Se}$; the determination was carried out by the recommended method. The results listed in Table 2 show that those ions at the tested concentrations could not affect the determination of Se when a $5 \mathrm{ng} \mathrm{cm}^{-3} \mathrm{Se}$ standard solution was used.

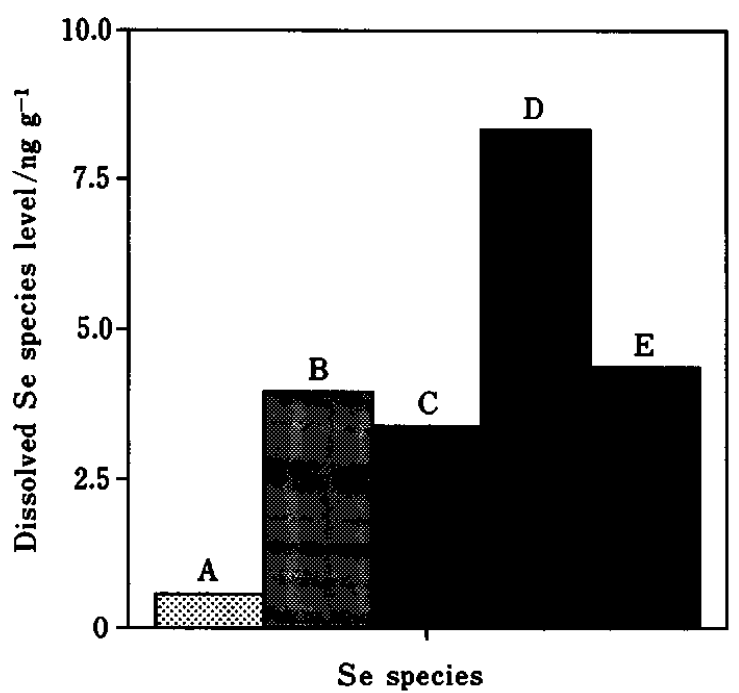

Fig. 2 Comparison of various Se species in hair. $A=S e(I V)$, $\mathrm{B}=\mathrm{Se}(\mathrm{IV})+(\mathrm{VI}), \mathrm{C}=\mathrm{Se}(\mathrm{VI}), \mathrm{D}=$ total dissolved $\mathrm{Se}$ and $\mathrm{E}=$ dissolved organic $\mathrm{Se}$.

Table 3 Levels of Se species distributed in human hair

\begin{tabular}{lc}
\hline \multicolumn{1}{c}{ Species } & Concentration $/ \mathrm{ng} \mathrm{g}^{-1}$ \\
\hline $\mathrm{Se}(\mathrm{IV})$ & $0.57 \pm 0.05(n=6)$ \\
$\mathrm{Se}(\mathrm{IV})+\mathrm{Se}(\mathrm{VI})$ & $3.95 \pm 0.04(n=6)$ \\
$\mathrm{Se}(\mathrm{VI})^{\mathrm{a}}$ & $3.38 \pm 0.07$ \\
Dissolved Se & $8.32 \pm 0.03(n=4)$ \\
Dissolved organic Se & $4.37 \pm 0.08$ \\
Total Se & $687.14 \pm 4.1 \quad(n=7)$ \\
Total organic Se & $683.19 \pm 4.8$ \\
\hline
\end{tabular}

a. $\{\mathrm{Se}(\mathrm{IV})+\mathrm{Se}(\mathrm{VI})\}-\mathrm{Se}(\mathrm{IV})$.

b. (Dissolved $\mathrm{Se})-\{\mathrm{Se}(\mathrm{IV})+\mathrm{Se}(\mathrm{VI})\}$.

c. (Total Se)-\{Se(IV)+Se(VI)\}.

\section{Soluble Se species in a human hair sample}

The levels of different Se species contained in a hair sample were determined by the HGAAS system under the optimized instrumental conditions mentioned above. From Fig. 2, it is noted that the amount of Se(IV) is the lowest among all of the Se species, and the sum of Se(IV) and $\mathrm{Se}(\mathrm{VI})$ is nearly equal to the level of dissolved organic Se. All of the Se species in a hair sample are listed in Table 3. The result implys that the organic Se in hair was hardly soluble in water. In addition, it can be determined that over $99 \%$ of the total Se in a hair sample is organic Se.

The level of the total Se obtained here is in accordance with that of the previous work ${ }^{17}$, in which the content of $\mathrm{Se}$ in the prepared hair sample was compared with a certified reference material ("NIES No. 5 Hair"). However, our obtained results concerning inorganic and organic Se were not absolute, because no reference materials act as a standard for estimating the Se species in 
a human hair sample at present. Se metabolism is a very complex process in vivo, and the organic Se in hair was less soluble in water. Although the main organic Se metabolites are known to be selenomethionine in milk and blood ${ }^{23}$, trimethylselenonium, selenoamino acid and selenoniocholine in blood and urine $\mathrm{e}^{24-26}$ and so on, organic Se species in hair are not yet known.

\section{References}

1. A. K. Das, R. Chakraborty, M. L. Cervera and M. de la Guardia, Mikrochim. Acta, 122, 209 (1996).

2. I. S. Krull (ed.), "Journal of Chromatography Library Series,".Vol. 47, Elsevier, Amsterdam, 1991.

3. X. Dauchy M. Potin-Gautier, A. Astruc and M. Astruc, Fresenius' J. Anal. Chem., 348, 792 (1994).

4. P. Borella, S. Rovesti, E. Caselgrandi and A. Bargellini, Mikrochim. Acta, 123, 271 (1996).

5. P. Quevauviller, E. A. Maier, K. Vercoutere, H. Muntau and B. Griepink, Fresenius' J. Anal. Chem., 343, 335 (1992).

6. Y. Tamari, M. Yoshida, S. Takagi, K. Chayama, H. Tsuji and Y. Kusaka, Bunseki Kagaku, 41, T77 (1992).

7. R. M. Olivas, O. F. X. Donard, C. Camara and P. Quevauville, Anal. Chim. Acta, 286, 357 (1994).

8. A. K. Macpherson, B. Sampson and A. T. Diplock, Analyst [London], 133, 281 (1988).

9. G.-H. Tao and E. H. Hansen, Analyst [London], 119, 333 (1994).

10. M. McDaniel, A. D. Shendrikar, K. D. Reiszner and P. W. West, Anal. Chem., 48, 2240 (1976).

11. G. A. Cutter, Anal. Chem., 57, 2951 (1985).
12. G. A. Cutter, Anal. Chim. Acta, 98, 59 (1978).

13. M. Verlinden, H. A. Deelstra and E. Adriaensses, Talanta, 28, 637 (1981).

14. K. Okamoto, M. Morita, H. Quan, T. Uehiro and K. Fuwa, Clin. Chem., 31, 1592 (1985).

15. Y. Tamari, K. Hiraki and Y. Nishikawa, Geochem. J., 12, 37 (1978).

16. Y. Nakaguchi, K. Hiraki, Y. Tamari, Y. Fukunaga, Y. Nishikawa and T. Shigematsu, Anal. Sci., 1, 247 (1985).

17. Y. Nakaguchi, X.-N. Dong, Y. Kitauchi and K. Hiraki, J. Fac. Sci. Technol. Kinki Univ., 32, 25 (1996).

18. Y. Nakaguchi, Y. Saito, X.-N. Dong, T. Fujii and K. Hiraki, J. Fac. Sci. Technol. Kinki Univ., 31, 23 (1995).

19. J. Pettersson, L. Hansson and Å. Olin, Talanta, 33, 249 (1986).

20. F. D. Pierce and H. R. Brown, Anal. Chem., 48, 693 (1976).

21. B. Welz and M. Melcher, Analyst [London], 109, 569 (1984).

22. B. Welz and M. Melcher, Analyst [London], 109, 577 (1984).

23. P. B. Moser-Veillon, A. R. Mangels, K. Y. Patterson and C. Veillon, Analyst [London], 117, 559 (1992).

24. A. J. Blotcky, G. T. Hansen, N. Borkar, A. Ebrahim and E. P. Rack, Anal. Chem., 59, 2063 (1987).

25. A. J. Blotcky, A. Ebrahim and E. P. Rack, Anal. Chem., 60, 2734 (1988).

26. J. S. Blais, A. Huyghues-Despointes, G. M. Momplaisir and W. D. Marshall, J. Anal. At. Spectrom., 6, 225 (1991).

(Received October 28, 1996)

(Accepted January 27, 1997) 